\title{
SOCIÁLNÍ SITUACE U DĚTÍ TRPÍCÍCH ENURÉZOU
}

\section{Alena Bockschneiderová, Romana Klečková}

Jihočeská univerzita vČeských Budějovicích, Zdravotně sociální fakulta, katedra supervize a odborné praxe

\section{Současný stav}

Poruchy vyměšování (enuréza, enkopréza) patří $\mathrm{k}$ nejčastějším dlouhodobým problémům $\mathrm{v}$ pediatrii a přinášejí dětem, které jimi trpí, psychické a sociální problémy. Řadou epidemiologických studií bylo prokázáno, že 15-20\% pětiletých má potíže s úniky moče. $\mathrm{V}$ dospělosti přetrvávají tyto potíže jen u $1 \%$ populace (Gut, J., Doležal, J., Ženíšek, J., 1999, s. 28).

Mnoho dětí má problémy s nočním pomočováním, některé z nich mají tyto problémy i ve dne. Nočním pomočováním (enuresis nocturna) se označuje mimovolné vyprazdňování močového měchýře během spánku. Stupeň pomočení může být různý, od zvlhčení spodního prádla po vyprázdnění celého močového měchýře. Noční pomočování přetrvávající po pátém roce života se považuje za patologické (Gut, J., Doležal, J., ŽZeníšek, J., 1999, s. 28).

Existuji 2 typy enurézy - primární (dítě se vždycky pomočovalo) a sekundární (dítě se začalo pomočovat po období, kdy již bylo schopné zůstat suché). Problém se vyskytuje nejčastěji mezi pátým až sedmým rokem a zřídka pretetrvává až do dvanácti let. Sekundární enurézou trpí častěji chlapci než dívky (Train, A., 2001, s. 110).

Primární enuréza je v současné době hodnocena jako biologicky podmíněná porucha. Základním problémem je zrání a rozvoj koordinace jednotlivých funkcí. U většiny dětí je enuréza spojena s velmi hlubokým spánkem, při kterém dochází $\mathrm{k}$ překročení funkční kapacity močového měchýře a jeho reflexnímu vyprázdnění bez navození bdělého stavu. Sekundární potíže bývají spíše podmíněné psychogenně. Bývají důsledkem nějaké traumatizace či nezvládnuté stresové situace (Janda, J., 1999, s. 30 $-32)$.

Významným ukazatelem u rozvoje sekundárních poruch jsou psychosociální faktory. Může jít o specifické zátěže, které narušují rozvoj regulace vyměšování, např. necitlivý trénink udržování čistoty, príliš náročný a neodpovídající aktuální vývojové úrovni dítěte, nebo naopak jeho zanedbání. Vzhledem k tomu, že potíže kontroly vyměšování lze chápat jako psychosomatický problém, bývá považována za možný zdroj psychosociálního stresu rodina, zejména pokud je rodinné prostředí disharmonické, emočně neuspokojivé a nefunguje zde adekvátním způsobem vzájemná komunikace (Vágnerová, M., 2002, s. 480-481).

Genetické predispozice jsou u enurézy udávány asi u dvou třetin postižených dětí (Gut, J., 1998, s. 39-40).

\section{Léčba}

Pomočování většinou neohrožuje tělesné zdraví, i když v některých př́padech může upozornit na závažné onemocnění. Každopádně může mít nepř́znivý dopad na psychiku dítěte. Pediatr rozhoduje o vyšetřovacím a léčebném plánu, poprrípadě o dalších konzultacích u specialisty (dětský nefrolog, urolog či psycholog). Efekt léčby nemusí být vždy okamžitý a rychlost zlepšení je zcela individuální a do značné míry záleží na otevřenosti vztahu a spolupráci jak dítěte, tak celé rodiny i lékaře (Gut, J., 1998, s. 39-40).

K léčbě patři i léčebná tělesná výchova. Existuje sestava cviků pro enuretiky založená na tréninku svěračů s jejich následnou relaxací. Nezbytným prvkem u léčby je edukace enuretického dítěte i rodinných př́slušníků. Cílem obecné edukace u dětí s nočním pomočováním je zlepšit informovanost, posílit aktivní péči o své zdraví, podpořit efektivnější způsoby prevence a léčení (Dejlová, M., Gut, J., Kolský, A., 1998, s. 40-41).

$\mathrm{K}$ dalším řešením noční enurézy patři také budící přístroje (alarm systémy) nebo farmaka (Gut, J., Doležal, J., Ženíšek, J., 1999, s. 56-66).

Sociální význam poruch regulace vyměšování Schopnost ovládat vyměšování a regulovat jej tak, aby byla respektována běžná společenská 
pravidla, je důležitým předpokladem přijatelného sociálního hodnocení. Nedostatek v této oblasti je tolerován pouze $\mathrm{v}$ raném dětství, a pokud přetrvává i později, je pro postiženého jedince značně stigmatizující. Znečištění močí či stolicí je obecně akceptovaným důvodem k odmítání a ztrátě prestiže. Sociální význam nezvládnutí regulace vyměšování je jednoznačně negativní. Vědomí, že určitý jedinec je postižen něčím takovým, respektive zápach, který problém signalizuje, vyvolává odpor, nechut', někdy i soucit. Oproti tomu není tento problém považován za tak závažný, aby byla postiženému přiznána nějaká privilegia, aby na něj ostatní brali větší ohledy.

Děti s poruchou regulace vyměšování nemají lehkou pozici ve skupině svých vrstevníků. Často bývají izolovány, neúčastní se mnoha aktivit $z$ důvodů, že by se mohl projevit jejich hendikep (Vágnerová, M., 2002, s. 483).

\section{Možnosti pro děti trpící enurézou}

Sdílení skupinové zkušenosti s dalšími lidmi (např. na letním táboře), kteři mají podobné zájmy nebo cíle, se ukazuje jako velmi užitečné. Pro člověka, který si prripadá se svým problémem osamocený nebo prímo vyčleněný ze společnosti „normálních“ lidí, přináší úlevu a posilu zjišsění, že není ve své situaci sám, že také někdo jiný se potýká se stejným trápením (Vágnerová, M., 2002, s. 483).

Dětem trpícím enurézou se nevěnuje velká pozornost, přestože tento problém je v populaci hojně zastoupen. Jedním ze subjektů, který se těmto dětem a jejich rodinám věnuje, je Sdružení pro enurézu (dále jen SEN). Tato organizace byla založena v roce 1997 a sdružuje pacienty trpící monosymptomatickou enurézou, jejich rodiny a odborníky zabývající se touto problematikou (lékaři, psychologové, střední pracovníci a jinî), stejně jako další jednotlivce, organizace a instituce, které mají vztah $\mathrm{k}$ těmto dětem. Sdružení usiluje o všestranné hájení zájmů nemocných enurézou a jejich rodin, iniciuje akce ve prospěch dětí s enurézou a seznamuje veřejnost $\mathrm{s}$ touto problematikou. Prosazuje také zkvalitnění zdravotnické péče pro takto postižené jedince (www.enureza.cz).

Pro děti, které trpí enurézou, jsou také pořádány letní tábory (dále jen LT). V České republice je pořádají dvě organizace zaměřující se pouze na práci s enuretickými dětmi, a to Psy- chiatrická léčebna Šternberk a Občanské sdružení Žlutý květ. Ministerstvo zdravotnictví České republiky (dále jen MZ ČR) umožňuje rehabilitační pobyt pro děti trpící poruchami vyprazdňování (enuréza i enkopréza) prostřednictvím projektu z programu Vyrovnání príležitostí pro občany se zdravotním postižením. Projekt Letní tábor pro děti trpící enurézou a enkoprézou je realizován od roku 2002 na základně Zdravotně sociální fakulty Jihočeské univerzity v Českých Budějovicích (dále jen ZSF JU).

\section{Cíl práce}

Cílem práce bylo zjistit, zda a jak onemocnění enurézou zhoršuje sociální status dítěte ve společnosti vrstevníků. V rámci vymezení sociálního statusu byly sledovány následující aspekty: vztahy a vazby mezi vrstevníky, reakce dětí s enurézou na zátěžové situace, samostatnost dětí, vzájemná spolupráce dětí, ochota spolupracovat a volnočasové aktivity dětí.

\section{Metodika výzkumu}

Sběr dat probíhal metodou zúčastněného, př́mého i skrytého pozorování. Pozorování bylo provedeno prostřednictvím účasti na 14denním Letním táboře pro děti trpící enurézou a enkoprézou, realizovaného ZSF JU. Výzkum probíhal v období červenec až prosinec 2007 a spočíval $\mathrm{v}$ dokreslení představy o dětech samotných, o jejich chování, o dané problematice a spojení teoretických poznatků s praktickými zkušenostmi. Pozorování bylo zaměřeno na sledování vztahů a vazeb mezi vrstevníky, samostatnosti, vyrovnávání se zátěžovými situacemi, vzájemnou spolupráci dětí a ochotu spolupracovat. Další použitou metodou byla analýza dokumentů. Byly prostudovány dotazníky vyplněné rodiči dětí pro zkvalitnění pobytu na letním táboře, dále dotazníky k získání ucelených informací o nemoci dítěte, o rodinném a sociálním zázemí dítěte, závěrečná zpráva od psychologa, záznamy z letního tábora od zdravotních sester a oddílových vedoucích. Poslední z využitých metod bylo dotazování technikou neř́zeného rozhovoru s dětmi (př́mo na letním táboře) a $s$ jejich rodiči ( $v$ domácím prostředî). Rozhovory byly koncipovány jako prrirozené dialogy, kterým předcházelo vytvoření přátelské atmosféry a vzájemné důvěry.

Z celkového počtu třiceti dětí účastnících se letního tábora pro děti trpící enurézou 
a enkoprézou v roce 2007, realizovaného ZSF JU, bylo původně osloveno 15 rodin, ale s výzkumem souhlasilo pouze 8 rodin.

\section{Charakteristika souboru}

Zkoumaný soubor tvorilo 8 dětí (3 dívky a 5 chlapců) s diagnózou enuréza z celé České republiky, účastnících se Letního tábora pro děti trpící enurézou a enkoprézou v roce 2007. Věkové rozmezí respondentů bylo od 9 do 15 let. Výzkumu se také účastnili rodiče těchto 8 dětí. Respondenti byli vybíráni kvótním výběrem, přičemž kvótou byla diagnóza enurézy a souhlas i ochota rodiny spolupracovat na výzkumu.

\section{VÝSLEDKY}

Výsledky výzkumu jsou u respondentů zpracovány a s ohledem na individualitu každého respondenta a jeho rodinu jednotlivě, $\mathrm{v}$ rámci př́padových studií.

Pro potřeby příspěvku uvádíme čtyři prrípadové studie a shrnutí všech prrípadových studií. Další prrípadové studie jsou $\mathrm{k}$ dispozici u autorek.

\section{PŘÍPADOVÁ STUDIE 1}

\section{Obsahová analýza}

Chlapec, 14 let. Žije ve společné domácnosti s matkou, nevlastním otcem (vlastní otec zemřel) a s mladším bratrem. Problémy s pomočováním má odmalička. Chlapec se pomočoval téměř každou noc až do jedenácti let. Již 1 rok neužívá medikamentózní léčbu ve spojitosti s enurézou (léky, které mu naordinoval jeho praktický lékař pro děti a dorost), kapičky do nosu vysadili již před 2 lety. Matka uznala za vhodné vysadit tuto léčbu, protože frekvence pomočování nebyla tak častá jako dřive. Nyní se pomočí prúbližně 1-2krát do měsíce. Na Letním táboře pro děti trpící enurézou a enkoprézou realizovaném ZSF JU v roce 2007 (dále jen tábor ZSF JU) se během čtrnácti dní pomočil třikrát.

\section{Rozhovor s rodičem (matkou)}

Dle výpovědi matky nebyly pleny odmalička odbourány. Přes den se nepomočoval (ani o poledním klidu v mateřské škole nebo doma), ale pravidelně se pomočil každou noc. Matka vypozorovala, že se většinou pomočil po 22 . hod. Chlapec byl na „všech možných testech“, ale nikde se nepotvrdila organická prričina. Vlastní otec synovi zemřel, ale ani tento fakt neměl, dle matky, vliv na onemocnění. Průběh enurézy byl stále stejný, občas ano, občas ne, vždy jen v noci. Do psychologické poradny nedocházeli, matka se bála, aby to syna neponížilo. O smrti otce sice nemluvil, neventiloval ven, držel vše v sobě, ale problém s pomočováním se nestupňoval, tak tomu nechala volný průběh.

Matka nevypozorovala situace, které by souvisely s pomočováním (např. neshody, špatná známka ve škole, nastydnutí apod.). Matka přímo sděluje: „Po špatné známce ve škole jsem mu někdy vynadala a nic. Jiný den bylo vše v pohodě a v noci se počůral." Jeden čas si zapisovali i deník suchých a mokrých nocí za pomoci sluníček, ale ani tyto záznamy jim nepomohly vysledovat nějaké situace, kdy by byla frekvence méně častá, nebo naopak častější. Téměř pořád se opakovaly „mokré“ noci, tak toho zanechali. Celkový obraz dne nikdy nezaznamenávali.

Když byl chlapec malý, tajil tento problém i před rodiči. Ráno dělal jakoby nic, schovával mokré spodní prádlo, zastýlal pomočené prostěradlo, styděl se. Na matčiny dotazy, zda v pokoji nic necítí, necítil.

Matka se svého syna snaží více obhajovat než její nový manžel. Sama trpěla pomočováním do patnácti let.

\section{Rozhovor $s$ dítětem}

Dle chlapcových slov už není pomočování tak časté, není to pro něho taková zátěž, nemusí se tolik stresovat, jestli to bude ráno ,zase horší“. Prášky ani kapičky už nebere.

Nedělá mu problémy hovořit o otci, který zemřel, spíše má sám někdy potřebu vypovídat se.

Nevypozoroval situace, které by mohly souviset s enurézou.

Dříve se snažil vše maskovat, když se $\mathrm{v}$ noci pomočil. Bylo mu líto, že se matka občas rozčilovala a musela hodně prát. $\mathrm{Na}$ otcovy výtky (nevlastní otec) reagoval dříve agresivněji, občas s výbuchy hněvu, ale nyní je vše v pořádku.

O pomočování jeho vrstevníci nevědí, tají to před nimi. Jen jeden kamarád ví o enuréze (navzájem u sebe přespávají, rodiny společně tráví dovolené apod.). Kamarád je středoškolák, 
dyslektik. Nikdy se ani jeden z nich tomu druhému kvůli jistému omezení neposmíval. Oba dva to berou tak, že každý z nich má nějakou „vadu“. Učitelé ve škole to také nevědí. Do pololetí sedmé třídy věděly o enuréze jen trrídní učitelky.

Školních výletů (i s přespáním) se chlapec účastní. Byl na lyžařském výcviku (ani jednou se tam nepomočil) a dvakrát na letním táboře, který nebyl zaměřen na enurézu. Závodně několik let provozuje karate, účastní se i soustředění. Jedenkrát se na soustředění pomočil, ale stačil po sobě vše rychle uklidit, aniž by si toho někdo všiml. Pro jistotu s sebou měl i zdravotnickou podložku, kterou si dal pod prostěradlo. Nikdo o ní nevěděl.

$\mathrm{Na}$ táboře ZSF JU byl již třikrát. Chlapec uvedl: „Nejvíce se mi líbí, že nemusím mít takové obavy, aby se mi to nepřihodilo. Soustředění mě v téhle věci mnohem více stresuje.“ $\mathrm{Na}$ jiné tábory už ani jezdit nechce. Na táboře ZSF JU se nemusí za pomočování stydět, vidí, že stejný problém mají i jiné děti, nikdo se nad nikým nevyvyšuje a každý rok se těši na kamarády, které zná již z předchozích let. Velmi se mu líbí i organizovanost celého tábora. $\mathrm{Na}$ jiných táborech nedokázal dodržovat pitný režim, necvičil si.

Doma pitný režim dodržuje, ale když je ve škole, tak na to tolik nemyslí. Občas si také zacvičí.

\section{Pozorování}

Chlapec je společenský, hovorný, nekonfliktní typ. Snadno se zapojuje do kolektivu, s ostatními bez problémů spolupracuje, dokáže si najít cestu ke každému, nad nikým se nevyvyšuje, ale vzhledem ke svému věku se více snaží upoutat na sebe pozornost.

Chlapec je samostatný, dokáže si vyrúidit i vyřešit své záležitosti. Plní své povinnosti (úklid, hygiena apod.).

O enuréze hovoří otevřeně, ale je mu to stále nepř́ijemné.

\section{PŘÍPADOVÁ STUDIE 2}

\section{Obsahová analýza}

Chlapec, 11 let. Žije společně s matkou, nevlastním otcem, starší a mladší sestrou. Každé z dětí v této domácnosti má jiného otce. Současný otec rodiny je vlastním otcem nejmladší dcery (narodila se v záŕí 2007).
Chlapec se pomočuje odmalička (každou noc). Kapky do nosu (kvůli pomočování) užíval jen pár měsíců, pak je vysadili. Matka se bála vedlejších účinků. Zároveň je astmatik a trpí migrénami.

$\mathrm{Na}$ táboře ZSF JU se během 14 dnů pomočil osmkrát (vždy v noci). Ze záznamů oddílové vedoucí se u tohoto chlapce občas objevovaly konflikty s některými vrstevníky.

\section{Rozhovor s rodičem (matkou)}

Dle matčiných slov má její syn problémy s pomočováním odmalička (již nácvik chození na nočník byl problematický). Podstoupili různá vyšetření, ale nikde se neprokázala organická vada. Navštívili i psycholožku. Tam se také nic neprokázalo.

Chlapcův vlastní otec př́liš pracuje. Nemá na syna čas. Chlapec by dle matky potřeboval ocenění od svého vlastního otce, které se mu nedostává. Chlapec srovnává vztah se svým otcem se vztahem starší sestry s jejím vlastním otcem. Té se její vlastní otec věnuje až př́liš. Současný otec rodiny by mohl být pro chlapce vzorem a mohl by mu vynahradit péči, které se mu od vlastního otce nedostává.

Suché a mokré noci si zaznamenávali. Nezjistili žádné situace, kdy by se pomočování opakovalo častěji. Matka si myslí, že se pomočování zhoršilo po narození nejmladší dcery. Chlapec na ni žárlí.

Chlapec na pomočování reaguje jako na fakt, nemá potřebu něco měnit, už si na tuto situaci zvykl, myslí si, že je to normální. Matka vše uklidí, vypere, chlapec se o nic nestará, není motivován, aby se něco zlepšilo. Matka uvedla: „Občas se stalo, že jsem ho v noci probudila, on si to ráno nepamatoval a když zjistil, že se pomočil, naštval se na mě, že je to moje vina, že jsem ho nevzbudila."

Starší sestra se chlapci neposmívá, ale je jí 16 let a někdy u ní přespávají kamarádky. Problém je v tom, že mají společný pokoj. Dcera si vždy postěžuje matce na zápach v pokoji.

K babičkám jezdí chlapec jen velmi nerad. Vlastní otec ho budí třikrát za noc, proto se mu „to" tam tolikrát nepríhodí.

Matku nejvíce mrzí, že nemá kamarády, neumí s nimi navázat kontakt, začlenit se, stydí se. Možná je to prý i kvưli tomu, že je silnější postavy, citlivější a touží po ocenění. Chlapec 
nechce chodit mezi vrstevníky ani do zájmových kroužků. Nejradši je sám nebo doma $s$ rodiči a mladší sestrou.

Chlapec má nízké sebevědomí, těžko se podřizuje jakémukoliv režimu. Učí se respektovat druhé a také se jim někdy podřizovat.

Sestra matky se do patnácti let také pomočovala.

\section{Rozhovor s dítětem}

Chlapec má 2 nejlepší kamarády. O enuréze tito kamarádi nevědí. Nikdy se mu to před nimi nestalo, dával si pozor.

Chlapec uvedl: „Když se počůrám, tak ráno vstanu, mamka se zeptá a pak to uklidí.“

Velice rád plave, jezdí na kolečkových bruslích, ale sám nebo s matkou, když jede ven na procházku s kočárem s mladší dcerou. Volný čas tráví u televize nebo počítače. Občas si přečte nějakou knihu. Matka ho nutí, aby chodil ven, ale on nechce. Letos navštěvuje letecký modelářský kroužek. Ten mu doporučil jeho nevlastní otec (když byl malý, rád si lepil letadla, ted' mohou mít společný zájem).

$\mathrm{Na}$ tábor nebo školní výlet s přespáním by nejel. Styděl by se. Na táboře ZSF JU byl již trrikrát a velmi se mu líbila prípravenost celého tábora. Znovu jet nechce (neví proč).

Necvičí si (nepamatuje si cviky, prý by mu to zabralo hodně času). Pitný režim se snaží dodržovat. Matka mu to pořád připomíná.

\section{Pozorování}

Chlapec je samotářský typ, těžko se podřizuje režimovým opatřením, vrstevníkům i autoritám. Nenavazuje nové vztahy. Mezi vrstevníky není moc oblíbený, jeho chování je někdy až moc dětinské, někdy je infantilní, jindy se vyvyšuje nad ostatní vrstevníky. Nerad spolupracuje s ostatními vrstevníky, není ochoten se podřizovat, není samostatný, své záležitosti si nedokáže sám vyřešit. V některých situacích je bezradný.

Jeho sebevědomí je velmi nízké, je tvrdohlavý, málo otevřený, nesvěřuje se. Velmi touží po ocenění a pochvale.

O pomočování nechce mluvit, je mu to nepříjemné, stydí se.

\section{PŘÍPADOVÁ STUDIE 3}

Obsahová analýza

Dívka, 10 let. Žije společně s matkou, otcem a mladší sestrou. Ve čtyřech letech se pomočo- vala každou noc. Kvưli enuréze užívala kapky do nosu 3 měsíce až půl roku (matka nevěděla přesně). Stav se zlepšil a kapky přestala užívat.

Nyní se pomočí jen výjimečně (max. jednou za měsíc).

$\mathrm{Na}$ táboře ZSF JU se nepomočila ani jednou. Dívka je bezproblémová, nekonfliktní typ.

\section{Rozhovor s rodičem (matkou)}

Dívka se přestala pomočovat už ve 14 měsících. Po jejích čtvrtých narozeninách jí zemřel děda. Rodiče jí to tajili, pak se to dozvěděla a od té doby se pomočovala. Matka s dcerou navštěvovala nefrologickou poradnu. Nebyla zjištěna organická příčina.

Dívka již navštěvovala základní školu, když jí byly předepsány kapky do nosu. Ty užívala max. půl roku. Matka uvedla: „Další rok a půl bylo vše $\mathrm{v}$ pořádku, ale $\mathrm{v}$ létě se opět $\mathrm{z}$ ničeho nic začala každý den pomočovat".

Psycholožku nenavštívily, samo to přešlo. Dívka má velmi tvrdý spánek. Téměř už 2 roky je vše $v$ pořádku.

Matka svoji dceru již nekontroluje, neví, jestli cvičí, zda dodržuje pitný režim. Dcera je dle matčiných slov velmi samostatná a dokáže si své záležitosti a povinnosti pohlídat sama.

V nedávné době zemřela babička. Matka měla obavu, aby se vše neopakovalo jako $v$ prrípadě dědečka. Nic se neděje, vše je $\mathrm{v}$ naprostém pořádku.

\section{Rozhovor s dítětem}

Dívka uvedla: „Mám mladší sestru, všichni se motají jenom kolem ní, jenom jí věnují pozornost. Je pěkně rozmazlená. “ Dívka se cítí odstrčená. Občas mívá zlé sny, už odmalička. Pomočování může podle ní souviset i se strachem (např. ze školy, z písemky, zkoušení apod.).

Když se jí to $\mathrm{v}$ noci prihodilo, svlékla povlečení i prostěradlo, odnesla prádlo do pračky a oznámila to matce.

Poté, co začala užívat kapky, se jí to stalo jen málokdy. Nyní kapky neužívá, zvykla si chodit v noci na toaletu. Sama se vždy probudí.

Hraje tenis, na kytaru a chodí na aerobik. $S$ aerobikem byla $i$ na soustředění na tři dny a jednou i na týden. Bydlela s děvčaty, které o jejím onemocnění vědí, tak s sebou měla igelitové prostěradlo. Jedenkrát se na tomto soustředění pomočila. Moc jí to vadilo a styděla se. Děvčata se jí neposmívala. 
Na táboře ZSF JU se jí velmi líbí. Jiné tábory jsou dle jejích slov bez programu, neorganizované, musela by si zvykat na nové lidi. Dále si je jistá tím, že se jí na tomto táboře nebude nikdo kvůli enuréze posmívat.

Stále se snaží dodržovat pitný režim. Večer raději tolik nepije. Bezprostředně po táboře cvičila, ted' už necvičí. Myslí si, že už žádné cvičení nepotřebuje.

\section{Pozorování}

Dívka je velmi samostatná, dalo by se říci předčasně dospělá. Spolupráce s ostatními vrstevníky jí nedělá potíže, stále chce být nejlepší, ale moc si nevěrí. Je velmi přemýšlivá, hovorná, perfekcionistka. Vrstevníkům se tolik nesvěřuje, ale nemá problémy s navazováním kontaktů. Bez problémů si zařídí i vyřeší své záležitosti.

\section{PŘÍPADOVÁ STUDIE 4}

\section{Obsahová analýza}

Chlapec, 10 let. Žije v úplné rodině s matkou, otcem a starší sestrou. Pomočování odmalička nepřestalo (vždy v noci). Medikamentózní léčbu neužívá. Pomočuje se téměř každý den.

$\mathrm{Na}$ táboře ZSF JU se pomočil desetkrát. Chlapec je nekonfliktní typ, ale ze záznamů oddílové vedoucí je patrné, že často bývá bezradný a plačtivý.

\section{Rozhovor s rodičem (přítomen otec i matka)} Organická prrícina enurézy byla u chlapce vyloučena. Podstoupili různá vyšetření, nic se neprojevilo. Spolupracovali i s psycholožkou - také nic.

Dělají záznamy suchých a mokrých nocí. Nevypozorovali žádné situace, u kterých by se průběh enurézy zhoršoval (např. častější výskyt prri fyzické nebo psychické zátěži apod.).

Matka popisuje synovu reakci na „mokrou“ noc takto: „Ráno ke mně přišel, koukal, nic neříkal, čekal, až se ho zeptám“. Nyní již sám poví, co se stalo. Pomáhá s úpravou lůžka a povlékáním.

Chlapec nikam bez rodičů nejezdí. Nejel ani na lyžařský kurz. Na táboře ZSF JU byl poprvé.

Někdy přespává u dvou kamarádů (ti o enuréze vědî) nebo u babičky (ta chlapce několikrát za noc budí, proto se mu to tam tak často nestává). Chlapec je velmi citlivý.

Chlapcova starší sestra měla problémy s denním pomočováním. Byla „líná“ dojít si na toaletu („neměla čas“). Pediatr dívce sdělil, že si musí čas na toaletu udělat. Od té doby bylo vše $\mathrm{v}$ pořádku.

Chlapcův otec měl také potíže s pomočováním (až do trínácti let). Časem vše samo odeznělo.

\section{Rozhovor s dítětem}

Chlapec si myslí, že by mohla enuréza souviset s dobou, kdy jde spát. Když je dlouho vzhůru, tak se mu to tolik nestává. Ráno někdy sám neví, jestli se mu to stalo, nebo ne. Matce to vždy sám řekne, dříve se styděl.

Moc by si přál svůj vlastní pokojík. Zatím se musí dělit o jednu místnost se sestrou.

Nejlepši kamarádka i sestra o pomočování vědí, ostatním kamarádům nic neřekl.

Mezi chlapcovy zájmy patří tenis a počítačový kroužek (učí se zde vyrábět komiksy).

Chlapec dodržuje pitný režim, večer pije opravdu jen malinko. Nyní má problémy s páteří (rychle vyrostl), chodí na rehabilitaci, denně cvičí cviky na záda. Cviky na posílení pánevního dna už zapomněl.

Na tábor ZSF JU by chtěl jet znovu. Velmi si pochvaloval pŕipravenost tábora, nemusel se tam stydět, už by se mu prý tolik nestýskalo. Jiného tábora se účastnit nechce.

\section{Pozorování}

Chlapec je uzavřený (důvěřuje lidem a komunikuje s nimi, až když je více pozná), zvyklý být s rodiči, úzkostlivý, nesamostatný (byl poprvé sám mimo domov na 14 dnî), nesdílný, nenápadný. Špatně snáší kolektivní aktivity, je raději sám. Nerad navazuje nové vztahy s vrstevníky, též nerad spolupracuje s ostatními.

Bývá často nerozhodný, raději říká ne (je to pro něho jistějšî), je zoufalý $z$ rychlého rozhodování. V zátěžových situacích potřebuje poradit, sám si neumí pomoci.

Své povinnosti plní, nemá problémy $\mathrm{s}$ autoritou (preferuje spíše ženy).

\section{SHRNUTÍ VŠECH PŘÍPADOVÝCH STUDIÍ}

Shrnutí těchto prípadových studií poukazuje na jisté podobnosti, které se opakují.

Z výsledků rozhovorů s rodiči dětí vyplynulo následující:

$\mathrm{V}$ pěti př́padech trpěl enurézou jeden $z$ rodičů. $U$ všech respondentů je patrné, že u nich byla vyloučena organická prríčina onemocnění. Všichni dotazovaní rodiče uvedli, že 
s problémem navštívili praktického lékaře pro děti a dorost, který jim následně doporučil různá vyšetření. Psychologické vyšetření podstoupili jen 2 respondenti.

Příčinou vzniku onemocnění by dle rodičů mohla být nějaká traumatizace nebo stresová situace. Šest dětí žije v úplné rodině, dvě děti vyrůstající v rozvedené rodině. Ve dvou rodinách by se, dle matek, na zhoršení průběhu onemocnění mohlo podílet narození mladšího sourozence, $\mathrm{v}$ jednom prípadě se matka domnívá, že by enuréza mohla souviset s úmrtím blízkého člena rodiny u dalších dvou rodin se matky domnívají, že by prvotní příčina mohla být spojena se stresovou reakcí na nezvyklou situaci, ve dvou rodinách je uvedena jako možná príčina onemocnění lenost a pohodlnost svých dětí dojít si na toaletu při nutkání na močení. $\mathrm{V}$ př́padě jedné rodiny rodiče vůbec netuší, co by mohlo být prvotní přičinou onemocnění.

Ve třech prípadech jsou rodiče perfekcionističtí (u svých dětí vyžadují totéž), v pěti príipadech jsou př́liš benevolentní (děti nemají povinnosti, vše za ně udělají a vyřeší rodiče). U pěti respondentů z osmi však nejsou rodiče př́liš důslední při kontrolování dodržování režimových opatření. Bud' vše nechávají na dětech a sami nejeví zájem, nebo jim na jejich otázku týkající se i enurézy stačí jakákoliv odpověd’ dítěte, kterou si následně neověří.

Sedm rodičů uvedlo, že vyzkoušeli snad úplně všechno. Od režimových opatření po různé léky. Ve dvou rodinách se situace týkající se enurézy zlepšila, jinde je průběh stále stejný. Rodiče už nevědí, co s tím. Tři matky vypověděly, že jejich děti jsou přecitlivělé, př́liš úzkostné, náladové. Rodiče šesti dětí tvrdí, že jejich děti mají nízké sebevědomí a projevují se u nich tendence sebepodceňování. Rodiče všech dětí uváděli, že po návratu z LT byly děti více „živé“, samostatnější, energičtějšíi, sdílnější.

$\mathrm{Z}$ výsledků rozhovoru a pozorování dětí vyplynulo následující: Tři děti byly na tomto táboře poprvé, pět dětí bylo již opakovaně. Všechny děti trpící enurézou uváděly, že se jim na táboře velice líbilo. Převažovaly dobré ohlasy na organizovanost a pripravenost programu. Celý den byly v pohybu a vůbec se nenudily. Každý den se dělaly jiné zajímavé aktivity. Jediné, co by na táboře zrušily, je cvičení. Sestavu rehabilitačních cviků, kterou si děti na LT osvojily, si všechny děti bezprostředně po táboře ještě párkrát zacvičily. Šest dětí udává, že pitný režim doma dodržují.

Všechny děti se za pomočování stydí, jsou si vědomy jistého omezení, které jim toto onemocnění přináší, mají obavy z přespávání mimo domov a neradi o svém problému hovoří. Děti trpící enurézou shodně vypověděly, že své onemocnění před svými práteli tajily nebo stále tají. Kamarádi dvou respondentů o jejich onemocnění vědí, a nikdy se jim kvưli enuréze neposmívali. Za své onemocnění se pět dětí stydí a nerady o něm hovoří, naopak tř́i děti si žádný problém spojený s enurézou nepřipouštějí.

Sedm respondentů nerado spolupracuje s ostatními dětmi. Mají strach z ponížení, z toho, že na ně bude svalována vina z nezdaru. Jeden respondent uvedl, že mu spolupráce s ostatními dětmi nevadí.

Dále je zřejmé, že preferují individuální zájmy před kolektivními aktivitami. Každé dítě tráví čas podle svých zájmů, možností a dostupnosti volnočasových aktivit. Paleta jejich zájmů je pestrá, je možné jmenovat tenis, atletiku, jízdu na kolečkových bruslích, plavání, hru na flétnu apod. $Z$ výpovědí dětí trpících enurézou je zř́ejmé, že se nejraději účastní aktivit, kde nemusejí spolupracovat s ostatními vrstevníky. Pokud jde o sport, vybírají si takový, kde hrají samy za sebe, nebo sport, kde úspěch či neúspěch je pouze jejich záležitostí.

\section{Vytvoření hypotézy}

$\mathrm{Na}$ základě kvalitativního výzkumu vznikla hypotéza: Děti trpící enurézou preferují individuální zájmové činnosti před kolektivními volnočasovými aktivitami.

\section{DISKUZE}

$\mathrm{Na}$ táboře je zaveden speciální režim a program tábora je upraven podle potřeb dětí (Bř́zová, 2006, s. 30-32). Většina dětí (5) byla na LT již opakovaně. Většina dětí (6) udává, že pitný režim doma dodržují. Bezprostředně po táboře si tyto děti ještě párkrát zacvičily. Pozornost, která je věnována upevnění hygienických návyků, je $z$ důvodu, že velký počet dětí nemá zafixované základní návyky zoblasti osobní hygieny (mytí rukou, sprchování, udržování pořádku v osobních věcech apod.). Hygiena je pritom důležitou součástí intervencí enurézy.

Vágnerová (2002, s. 483) uvádí, že pro dítě, které si připadá se svým problémem osamoce- 
né, nebo př́mo vyčleněné ze společnosti vrstevníků, přináší úlevu a posilu zjištění, že není ve své situaci samo, že také někdo jiný se potýká se stejným trápením. Otevírá se možnost mluvit o starostech dosud nesdílených a jakoby nesdělitelných s někým, kdo má obdobné těžkosti. Všechny děti trpící enurézou uváděly, že se jim na táboře velice líbilo, jediné, co by na táboře zrušily, je cvičení. Rodiče dětí též uváděli, že po návratu z LT byly děti více „živé“, samostatnější, energičtější, sdílnější.

Jak uvádí Janda (1999, s. 30-32), rozvoj neorganické poruchy vyměšování bývá podmíněn multifaktoriálně. Primární enuréza je v současné době hodnocena jako biologicky podmíněná porucha. Základním problémem je zrání a rozvoj koordinace jednotlivých funkcí. Sekundární potíže bývají spíše podmíněné psychogenně. Bývají důsledkem nějaké traumatizace či nezvládnuté stresové situace. Organická prríčina byla u všech respondentů vyloučena. Příćinou vzniku onemocnění by dle rodičů mohla být nějaká traumatizace nebo stresová situace.

Gut, Doležal a Ženíšek uvádějí (1999, s. 28 -29), že až v $70 \%$ prípadů trpěl enurézou $i$ jeden $z$ rodičů nebo sourozenec. Není zcela jasné, o jaký typ dědičnosti jde, lze předpokládat, že bude poněkud složitější, závislý na interakci více genů. Z výsledků vyplynulo, že $\mathrm{v}$ pěti případech trpěl enurézou jeden $\mathrm{z}$ rodičů.

Významným ukazatelem jsou dle Vágnerové (2002, s. 480-481) psychosociální faktory, které bývají velmi důležité u rozvoje sekundárních poruch. Může jít o specifické zátěže, které narušují rozvoj regulace vyměšování, a potíže kontroly vyměšování lze chápat jako psychosomatický problém. Za možný zdroj psychosociálního stresu může být pokládána rodina, zejména pokud je rodinné prostředí disharmonické, emočně neuspokojivé a nefunguje zde adekvátním způsobem vzájemná komunikace. Riziko vzniku poruch regulace vyměšování mohou posilovat i jiné aktuální stresy, traumatické zážitky nebo jen obavy úzkostného dítěte z vyměšování mimo domov. Většina dětí (6) žije $\mathrm{v}$ úplné rodině, dvě děti vyrůstající v rozvedené rodině. Všechny děti mají obavy a strach z přespávání mimo domov. Podle rodičů by se na zhoršení průběhu onemocnění mohlo podílet narození mladšího sourozence (2), úmrtí blízkého člena rodiny (1), stresová reakce na nezvyklou situaci (2), lenost a pohodlnost dětí dojít si na toaletu při nutkání na močení (2). Jeden rodič uvedl, že vůbec netuší, co by mohlo být prvotní prríčinou onemocnění.

Jak uvádí Gut (1999, s. 39-40), o problému je třeba beze studu hovořit jak $\mathrm{v}$ rodině, tak i s dětským lékařem. Ten rozhodne o vyšetřovacím a léčebném plánu, poprúpadě i o dalších konzultacích u specialisty. Tím může být dětský nefrolog, urolog či psycholog. Všichni dotazovaní respondenti uvedli, že s problémem navštívili praktického lékaře pro děti a dorost, který jim následně doporučil různá vyšetření. Psychologické vyšetření podstoupili jen 2 respondenti.

Jak tvrdí Dunovský (1999, s. 76-77), místo, pozici si každý získává podle toho, jak ostatní členové skupiny oceňují jeho př́nos pro plnění společného cíle. Sociální vývoj a postavení člověka jsou zásadním způsobem ovlivňovány jeho zdravotním stavem. Děti trpící enurézou shodně vypověděly, že své onemocnění před svými přáteli tajily nebo stále tají. Kamarádi dvou respondentů o jejich onemocnění vědí, a nikdy se jim kvưli enuréze neposmívali. Sedm respondentů nerado spolupracuje $s$ ostatními dětmi. Mají strach z ponížení, z toho, že na ně bude svalována vina $\mathrm{z}$ nezdaru. Jeden respondent uvedl, že mu spolupráce s ostatními dětmi nevadí. Výzkum potvrdil, že tyto děti mají nízké sebevědomí a projevují se u nich tendence sebepodceňování. Za své onemocnění se stydí, neradi o něm hovoří, naopak někteři si ho ani nepřipouštějí. Některé děti jsou, dle matek, přecitlivělé, př́liš úzkostné, náladové.

Vágnerová (2002, s. 480-481) uvádí, že rodiče reagují na enurézu různými způsoby. Odlišnosti jsou i v jejich následném chování. U některých převažuje zoufalství, pocit bezmoci, pasivita, stejně tak může problém rodiče aktivizovat. Sedm rodičů uvedlo, že vyzkoušeli snad úplně všechno, od režimových opatření po různé léky. Ve dvou rodinách se situace týkající se enurézy zlepšila, jinde je průběh stále stejný. Někteří rodiče nejsou př́liš důslední při kontrolování dodržování režimových opatření (5). Bud' vše nechávají na dětech a sami nejeví zájem, nebo se jen zeptají a stačí jim jakákoliv odpověd', kterou si následně neověří.

Dle Langmeiera (1998, s. 101-104) je vliv trávení volného času na vývoj osobnosti je vel- 
mi důležitý. Ukazuje se, že volba činnosti ve volném čase závisí více na osobních vlastnostech než na věku. Na základě výzkumu můžeme konstatovat, že každé dítě tráví čas podle svých zájmů, možností a dostupnosti volnočasových aktivit. Paleta jejich zájmů je pestrá, od sportovních aktivit až po hru na hudební nástroj. Z výpovědí je zřejmé, že děti trpící enurézou se nejraději účastní aktivit, kde nemusejí spolupracovat s ostatními vrstevníky. Pokud jde o sport, vybírají si takový, kde hrají samy za sebe, nebo sport, kde úspěch či neúspěch je pouze jejich záležitostí.

\section{ZÁVĚR}

Děti s poruchou regulace vyměšování nemají ve skupině svých vrstevníků lehkou pozici. Casto bývají izolovány, neúčastní se mnoha aktivit $z$ důvodů, že by se mohl projevit jejich hendikep. Děti s enurézou se ostatním dětem bez enurézy na jedné straně vyhýbají, protože se za pomočování stydí, na druhé straně touží po sociálním kontaktu a chtěly by se sostatními vrstevníky kamarádit. Sociální postavení dětí trpících enurézou je tedy problematické, ale zřejmě ne natolik, aby se s těmito dětmi pracovalo stejně jako s dětmi s jiným typem hendikepu.

$\mathrm{Na}$ základě kvalitativního výzkumu bylo zjištěno, že sociální status dětí trpících enurézou je ohrožen.

Podle autorek by bylo vhodné, aby měly tyto děti stejné možnosti jako děti bez problémů s vyměšováním. $V$ současné době mohou tyto děti „pouze“ strávit část prázdnin jako je- jich vrstevníci bez diagnózy enuresis na Letním táboře pro děti trpící enurézou a enkoprézou.

Vzhledem k tomu, že se o problematiku poruch vyměšování zajímají zejména pediatři, nefrologové, psychiatři a psychologové, jsou dostupné výzkumy zaměřené pouze $v$ rámci těchto oborů. Jinak to není ani u publikací, které se věnují problematice enurézy. Př́nos práce tedy shledáváme $\mathrm{v}$ možnosti využití výsledků v pomáhajících profesích. Výsledky mohou být základem pro další studie a výzkumy nejen v oblasti sociální práce, kde je velmi nutná orientace na osobní identitu dítěte.

\section{LITERATURA}

BŘÍZOVÁ, B.: Zhodnocení letních táborů pro děti s enurézou, enkoprezí a inkontinencí v letech 2004 a 2005. Vox pediatrie. Časopis praktických lékařu pro dèti a dorost. 2006. roč. 6, č. 3, s. 30-32.

DEJLOVÁ, M., GUT, J., KOLSKÝ, A.: Vyšetření dítěte s enurézou v ordinaci praktického lékaře. Československá pediatrie. 1998. roč. 53, č. 1, s. 40-41.

GUT, J.: Co je v duši enuretického dítěte? Československá pediatrie. 1998. roč. 53, č. 1, s. 39-40.

GUT, J., DOLEŽAL, J., ŽENÍŠEK, J.: Pomočování u dětí. Praha: Galén, 1999. $88 \mathrm{~s}$.

JANDA, J.: Noční pomočování. Postgraduální medicína. 1999. roč. 1, č. 1, s. 30-32.

LANGMEIER, J., KREJČÍKOVÁ, D.: Vývojová psychologie. Praha: Grada, 1998. 344 s.

Obecné informace - enuréza. Sdružení pro enurézu. [online]. [cit. 2008-04-16]. Dostupné z: http:// www.enureza.cz/obecne-informace.

TRAIN, A.: Nejčastější poruchy chování dětí. 1. vydání. Praha: Portál, 2001. 200 s.

VÁGNEROVÁ, M.: Psychopatologie pro pomáhající profese. 3. vydání. Praha: Portál, 2002. 444 s.

\section{Alena Bockschneiderová a Romana Klečková}

abock@zsf.jcu.cz 